\title{
Application of Mobile Learning Based on Mobile Phone APP in College Sports Teaching
}

\author{
Take "Ulearning" as an Example
}

\author{
Fei Dai \\ Wuchang Institute of Technology \\ Wuhan, China
}

\author{
Junhong Shu \\ Wuchang Institute of Technology \\ Wuhan, China
}

\begin{abstract}
With the continuous social and economic development, people's material standard of living improves accordingly. At present, smart phones have become an indispensable tool in people's daily life. With the soaring development of communication technology, mobile phones play a distinctly important role in many fields. Mobile phone APP is introduced in sports teaching. The combination of mobile phone APP and traditional teaching pattern stimulates students' learning interests in sports and improves their learning ability, helping them to do physical training in daily life. The cloud platform of "Ulearning" with smart teaching adopts the popular form of micro course suitable for colleges to carry out blending teaching. It is discussed in this paper from for aspects: the advantages and significance of bringing mobile phone APP in sports teaching; principles of applying mobile phone APP to sports teaching, strategies to use mobile phone APP in independent learning and notes in using mobile phone APP.
\end{abstract}

\section{Keywords $\longrightarrow$ sports teaching; APP; Ulearning}

\section{INTRODUCTION}

With continuous popularization of mobile terminal devices, a new learning form appears in sports teaching and training. Different from the traditional learning style, mobile learning is an innovative expansion. The teaching method concentrates knowledge points and units in the classroom to educate students through multimedia functions in mobile terminals. The teaching method has portability and autonomy. The learning style will not be constrained by space and time. The flexible learning style breaks the limitation of resources and space in sports teaching, which is convenient for students to seek resources of sports teaching. Mobile phone APP is software navigation and game provided by third-party service. Users can carry out operation like on the computer through independent operation system and space and receive wireless network and mobile communication network. Smart phones play an increasingly important role in people's daily life. The significance and functions of mobile phone APP in sports teaching are analyzed, in order to provide new ideas for

Fund program: Provincial teaching research project of universities in Hubei, project name and number: Research on Application of Micro Course Resources Based on "Ulearning" Cloud Platform in College Sports Teaching 2016450. sports teaching.

\section{SignifiCANCE AND AdVANTAGES OF BRINGING MOBILE PHONE APP IN SPORTS EDUCATION}

Smart phones are small and portable as well as continuous improvement of intelligence level. Students can independently and conveniently shoot videos and accumulate learning materials in sports teaching. Interactive software exists in mobile phone APP for students to communicate and improve sport technique.

The traditional teaching focuses on single and rigid textbooks, making students lose interests in classroom learning. As an interactive platform, mobile phone APP has strong multimedia environment to provide colorful information for students, so students have great interests in it and can use it skillfully. More than 90 percent of students surf the internet through mobile phones and electronic products. Some students with weak ability of self-discipline even use mobile phones in classroom teaching. The combination of mobile phone APP and traditional educational pattern can make students have new understanding of sports teaching. Meanwhile, it draws the distance between sports teaching and students close and stimulates students' interests in sports learning.

In traditional sports teaching, teachers demonstrate actions and explain the practice methods of the sport technique in class for students to grasp through spending a lot of time in imitation and training. It is not enough to teaching in class to grasp a new sport technique. The bringing of electronic products like mobile phone APP in sports teaching enables students to understand the actions through videos and actions and train according to their characteristics instead of only depending on teachers. The intuitive way makes students more clearly understand their defects in sports learning and breaks the limitation of physical education teachers in touring guidance in teaching the whole class. The independent evaluation, test and learning on mobile phone APP can train students' self-study ability and good exercise habit. The sports teaching through mobile phone APP is a novel teaching method that arouses students' interests and activates classroom climate. The relationship between teachers and students will be closer through emotional communication when they teach and learn 
through pictures and videos of skilled movement. Traditionally, teachers have to simulate and explain or directly communicate with students to correct the wrong actions. But with the combination of mobile phone APP and sports teaching, students can learn independently and the teaching efficiency and quality is improved. Mobile phone APP is increasingly popular and has become a necessary tool of us. Students can do physical exercise in spare and free time. It changes the traditional teaching pattern confined to the classroom. The absence of restriction in time and space greatly makes sports learning more flexible and helps students achieve the goal of lifelong sport.

In sports teaching, many excellent PE teachers have rich theoretical experience but fail to demonstrate actions because of the limitation of physical qualifications. Mobile phone APP can help them to demonstrate and explain actions so it is easier for students to learn. Sports teaching can be diversified in mobile phone APP. Students can choose different kinds of favorite sports to learn.

\section{PRINCIPLES OF APPLYING MoBILE PHONE APP TO SPORTS TEACHING}

The primary purpose of applying mobile phone APP to sports teaching is to improve students' efficiency in learning sport techniques. Teachers should continuously strengthen the purpose in sports teaching. It is the precondition and strong guarantee to apply mobile phone APP to sports teaching to guarantee good teaching order.

Teachers should make some changes in preparing lessons because of the introduction of mobile phone APP. In order to furthest exert the functions of mobile phone APP in sports teaching, teachers have to make sufficient preparations to know clearly about each part of the course and the application time of mobile phones in class. They should design the time and link of using mobile phones in class in advance, provide methods and emphasis of using mobile phones in class and further communicate with students in charge of sports activities. In addition, the preparation of videos and pictures can ensure the smooth classroom teaching. Because not all students submit themselves to teacher's direction, teachers should guide and educate students who violate discipline according to supervision system. After the class is over, teachers have to conclude the class and the effects of using mobile phones.

\section{STRATEGIES TO USE MOBILE PHONE APP IN INDEPENDENT SPORTS LEARNING}

Students can communicate in independent sports learning through interactive function of mobile phones. Many internet applications with strong interactive function exist in mobile phone APP. Students can communicate with teachers and classmates and share their understanding and experience after class. It disperses classroom education to free time, which is convenient for teachers to carry out distance teaching and students to learn independently. Furthermore, students can update their training condition and results on WeChat and weibo. Teachers can effectively guide and explain the difficulties faced by students in independent learning.

The integration of mobile phone APP in sports teaching helps students to implement self-testing and selfimprovement independently after class and better control time in training. They reasonably distribute time and formulate more reasonable training plan, in order to make the independent learning more pertinent and efficient.

\section{NOTES OF USING MOBILE PHONE APP IN SPORTS TEACHING}

It is a novel and scientific method to combine the traditional teaching pattern with mobile phone APP. School leaders and administrative departments should change idea and rationally treat the application of mobile phone APP in teaching, provide a better system for improvement of sports teaching method. Meanwhile, the change of thought can provide a better public opinion environment for the new sports teaching method.

The application of mobile phone APP in teaching is a double-edged sword. We should eliminate negative effects and reasonably solve problems, in order to let the new teaching method yield twice the result with half the effort. But if teachers neither strictly control the application of mobile phone APP nor guide students, the teaching method may run counter to our expectations.

Teachers should clearly know mobile phone APP is only a supplementary means of teaching and an effectively tool to improve teaching efficiency. The detailed explanation to students is still necessary, so it has higher requirements for comprehensive ability of PE teachers. Teachers shouldn't completely depend on mobile phones in teaching. The excessive dependence on mobile phones will make teachers not enthusiastic about the research on teaching. Only the combination of teachers' teaching with the teaching of mobile phone APP can achieve better teaching effects.

\section{CONCLUSION}

The application of mobile phone APP in sports teaching is a modern teaching method. It completely changes the traditional teacher-centered teaching pattern, expands teaching contents of traditional sports and upgrades the depth and width of sport knowledge. The new teaching pattern meets students' requirements of personalized development and lifelong sports, referring to a reform of sports teaching method. Moreover, with the popularization of mobile phone APP among students, students can carry out independent and mobile learning. The unceasing development of application functions and researches of mobile phone APP will inevitably bring richer learning experience for students.

\section{REFERENCES}

[1] Liu Lin, Liu Ying. Research on Mobile Learning Based on Mobile Phone APP in College Education [J], Journal of Changsha Social Work College, 2014(02) 
[2] Cao Yan, Lei Tinan. Design and Practice of Mobile Learning Based on Mobile Phone APP [J], China Education Info, 2013 (24)

[3] Zhang Min. Design Strategy of English Micro Course in the Era of Fragmented Learning - Take the Micro Course Work of English Guessing Word Skills as an Example [J], Higher Vocational Education(Journal of Tianjin Vocational Institute, 2016 (04)

[4] Zhang Chenggong, Liu Xiaoying. Research on Design of Contents in Ubiquitous Learning in Regional History and Culture Based on WeChat Official Account-Take the Ancient Capital Datong as an Example [J], China Education Info, 2016 (22)

[5] Hu Xiaofeng. Reform and Practice of Course Teaching Pattern in Accounting Major Based on Mobile Learning [J], Journal of Heilongjiang College of Education, 2016 (11)

[6] Xu Fangfang. Research on Design of Contents to Promote the Deep Learning of Knowledge in Flipped Classroom [J], China Modern Educational Equipment, 2016 (21)

[7] Deng Yuanyuan, Wu Qinjin. Mobile Learning: New Perspective of Teaching Reform in Colleges [J], Journal of Chifeng University (Philosophy and Social Science Chinese Edition), 2016 (11) 